\title{
SMART CITY RANKING WITH SUBJECTIVE INDICATORS
}

\author{
Adam SOJDA \\ Silesian University of Technology, Zabrze; adam.sojda@polsl.pl, ORCID: 0000-0002-3021-4451
}

Purpose: The primary purpose of the presented work is to show the impact of the residents' opinion on the formation of the city's position in the SCR ranking. Another objective was to draw attention to the problem of data shortages in publicly available databases.

Design/methodology/approach: The primary database of European countries is the Eurostat database. The research area covered cities with a population of between 200,000 and 800,000, which were not national capitals. Only one city from each country was selected. The proposed SCR covers six areas related to Smart City concept. Two types of meters for each of them are proposed - the first based on objective measures, the second on subjective measures, i.e. the opinions of residents. Each factor was standardised and transformed. The higher the value of the factor, the greater the positive effect on the index.

Findings: Cities from the database were identified. General ranking and rankings for both objective and subjective meters were created. The relationship between rankings was investigated, and the impact of subjective variables was shown to be significant.

Originality/value: The original method for determining the Smart City index was proposed. It is shown that subjective measures should be included in the rankings. The opinion of the residents should be taken into account when building a ranking regarding Smart City concept.

Keywords: Smart City, Eurostat, sustainable, European cities, indicators.

Category of the paper: Research paper.

\section{Introduction}

It is assumed that by 2030 , more than $60 \%$ of the population will live in cities (United Nations 2014). Economic growth is expected to take place with their participation. It is important to ensure adequate living conditions to enable this growth. It is essential to acquire skills in the assessment of the initiatives taken by cities in this process. 
The city should know its strengths and weaknesses. The Smart City concept makes it easy to assess the city. This concept is continuously being developed. Currently, we can talk about Smart City 5.0 (Svítek 2020). Its hierarchical structure facilitates the assessment of the city according to this concept. It is possible to divide it into sub-areas, factors and indicators (Ahvenniemi et al., 2017; Albino et al., 2015; Bosch et al., 2017a; Huovila et al., 2016; Stankovic et al., 2015; Lombardi, 2011; Tahir, 2016). Complexity means that there is no transparent assessment system. There are many concepts of a Smart City (Albino et al., 2015; Berrone et al., 2019; Bosch et al., 2017b.; Giffinger et al., 2007; Smart City PROFILES, 2013; Szczech-Pietkiewicz 2015; UCLG 2012).

Table 1.

Smart City Index

\begin{tabular}{|c|c|c|l|}
\hline INDEX & $\begin{array}{c}\text { Number of } \\
\text { Categories }\end{array}$ & $\begin{array}{c}\text { Number of } \\
\text { Indicators }\end{array}$ & \multicolumn{1}{|c|}{ INFO } \\
\hline $\begin{array}{c}\text { European Smart } \\
\text { Cities Ranking }\end{array}$ & 6 & 64 & $\begin{array}{l}\text { European ranking compiled by an international } \\
\text { consortium chaired by the University of Technology in } \\
\text { Vienna. }\end{array}$ \\
\hline $\begin{array}{c}\text { The Smart Cities } \\
\text { Wheel }\end{array}$ & 6 & 62 & $\begin{array}{l}\text { A holistic assessment system, taking into account the key } \\
\text { elements that make up a Smart City. }\end{array}$ \\
\hline $\begin{array}{c}\text { Bilbao Smart } \\
\text { Cities Study }\end{array}$ & 6 & 21 & $\begin{array}{l}\text { The idea initiated at the world summit in Bilbao, giving } \\
\text { an overview of the situation in cities of different regions } \\
\text { of the world. }\end{array}$ \\
\hline $\begin{array}{c}\text { Smart City } \\
\text { PROFILES }\end{array}$ & 5 & $\begin{array}{l}\text { Smart City indicators, with particular emphasis on } \\
\text { climate change and energy efficiency. }\end{array}$ \\
\hline
\end{tabular}

The categories, areas in which we perceive Smart Cities include: smart economy (ECO), intelligent population (PEO), smart management (GOV), intelligent mobility (MOB), intelligent environment (ENV), intelligent living conditions (LIV).

Many rankings have been built, and there will probably be new ones. Due to the multidimensional nature of the issue, every attempt to define and understand it is important. This issue matters not only from the researchers' but also from the city managers' point of view. It allows them to identify areas where development needs to be significantly improved.

The construction of the Smart City rating is labour-intensive. It requires access to a database which often requires separate research. City rating is possible compared to other cities. Solutions should be sought to make the comparison possible without requiring additional financial resources.

The most important rankings are based on objective measures. One should not forget that the city is for the people. Smart City activities to serve people are designed. Therefore, there is a concept of building an indicator using subjective meters. The use of subjective meters is undoubtedly dictated by the cost of obtaining data and quickly checking their reliability. Research often concerns economically and culturally different areas. The perception of the same question can vary considerably. This causes additional problems when interpreting the data. 
The aim of the research is to create a ranking of smart cities based on reliable and open data sources. The proposed meters were used in the construction of other indicators. They are also recommended by international organisations. In this paper the author decided to use a reliable data source such as Eurostat. Eurostat is a well-founded source of data. It has extensive databases of national and regional statistics. City related data are located in the Urban Audit database (Sojda et al., 2018). The activity area, however, is associated with significant deficiencies. The most complete information we can receive concerns the age of the inhabitants. The availability of other information can be different.

\section{Data and Methods}

\subsection{Data}

The data source was the Eurostat database, from which Urban Audit was used for city section. The study found that there were 572 variables in the database. 231 variables are of an objective nature. The remaining 341 are subjective assessments of the inhabitants, they correspond to a variable expressed in the five-stage Likert scale. The number of cities or urban areas is 1,822 . The cities are located in 32 countries. The data relate to the period from 1990 to 2019.

In most articles, attention is focused on large cities. Very often, work is limited to capital cities. This is usually due to the availability of data. The capital is a city with which the state identifies and transmits a lot of data about it. In this work, it was decided to depart from this principle - it covers cities from 100,000 to 500,000 inhabitants. Also, it was assumed that the city could not be the capital of a given country. These main assumptions further limited the availability of data in the Eurostat database.

Data analysis allowed to select 14 cities that matched the above criteria. It should be noted that not all cities had a full set of data. Data deficiencies had an impact on the rejection of factors. Factors with little coverage in the data were rejected.

Statistics were checked, and those variables that had little volatility were rejected. Variables with outliers are left. These values indicate an advantage over other cities. This was considered inappropriate for the construction of the ranking. It is assumed that standardisation is an effective process of levelling the playing field.

It was not possible to obtain such a set of factors which would cover the data for all the cities indicated. The data gaps were supplemented by searching the database to supplement the latest existing information. The value found replaced the lack of data. If the information could not be found, it was replaced by the worst relative value. 
For data related to the perception of cities by their citizens expressed on the Likert scale, the following solution was adopted. Weights $(-2 ;-1 ; 0 ; 1 ; 2)$ are assigned to the response: (strongly disagree, very unsatisfied; somewhat disagree, unsatisfied; do not know/no answer, somewhat agree, rather satisfied; strongly agree, very satisfied). This allowed determining a synthetic answer to the question.

Variable values have been normalised (Kukuła, 1989, 2000; Sojda et al., 2020). The following tables list the indicators assigned to the relevant areas of the ranking.

Table 2.

Indicators (INDIC) in ranking

\begin{tabular}{|c|c|c|c|}
\hline INDIC & NAME & MD & SD \\
\hline ECO O1 & Activity rate & 1 & $\mathrm{~S}$ \\
\hline $\mathrm{ECO} \mathrm{O} 2$ & All companies per 1,000 inhabitants & 1 & $\mathrm{~S}$ \\
\hline $\mathrm{ECO} \mathrm{O3}$ & Unemployment rate & 0 & $\mathrm{D}$ \\
\hline ECO S1 & In this city, it is easy to find a good job & 0 & $\mathrm{~S}$ \\
\hline ECO S2 & Most important in my city: unemployment & 0 & $\mathrm{D}$ \\
\hline ECO S3 & You have difficulty paying your bills at the end of the month & 0 & $\mathrm{D}$ \\
\hline ENV O1 & Annual average concentration of $\mathrm{NO} 2\left(\mu \mathrm{g} / \mathrm{m}^{3}\right)$ & 0 & $\mathrm{D}$ \\
\hline ENV O2 & Annual average concentration of PM10 $\left(\mu \mathrm{g} / \mathrm{m}^{3}\right)$ & 1 & $\mathrm{D}$ \\
\hline ENV O3 & Number of days particulate matter PM10 concentrations exceed $50 \mu \mathrm{g} / \mathrm{m}^{3}$ & 1 & $\mathrm{D}$ \\
\hline ENV S1 & Most important in my city: air pollution & 0 & $\mathrm{D}$ \\
\hline ENV S2 & The cleanliness in the city & 0 & $\mathrm{~S}$ \\
\hline ENV S3 & $\begin{array}{l}\text { This city is committed to the fight against climate change (e.g.; reducing } \\
\text { energy consumption in housing or promoting alternatives to transport by } \\
\text { car) }\end{array}$ & 0 & $\mathrm{~S}$ \\
\hline PEO O1 & $\begin{array}{l}\text { Employment (jobs) in professional, scientific and technical activities; } \\
\text { administrative and support service activities (NACE Rev. 2, M and N) }\end{array}$ & 1 & $\mathrm{~S}$ \\
\hline $\mathrm{PEO} \mathrm{O} 2$ & Median population age & 1 & $\mathrm{D}$ \\
\hline PEO O3 & $\begin{array}{l}\text { Proportion of population aged 25-64 qualified at level } 5 \text { to } 8 \text { ISCED, } \\
\text { from } 2014 \text { onwards }\end{array}$ & 2 & $\mathrm{~S}$ \\
\hline PEO S1 & Foreigners who live in this city are well integrated & 0 & $\mathrm{~S}$ \\
\hline PEO S2 & Most people in my neighbourhood can be trusted & 0 & $\mathrm{~S}$ \\
\hline PEO S3 & Schools in the city & 0 & $\mathrm{~S}$ \\
\hline LIV O1 & Infant mortality rate (per 1,000 live births) & 0 & $\mathrm{D}$ \\
\hline LIV O2 & $\begin{array}{l}\text { Number of deaths per year under } 65 \text { due to diseases of the circulatory or } \\
\text { respiratory systems per } 1,000 \text { inhabitants }\end{array}$ & 1 & $\mathrm{D}$ \\
\hline LIV O3 & Number of murders and violent deaths per 1,000 inhabitants & 3 & $\mathrm{D}$ \\
\hline LIV S1 & Health care services offered by doctors and hospitals in this city & 0 & $\mathrm{~S}$ \\
\hline LIV S2 & Most important in my city: social services & 0 & $\mathrm{D}$ \\
\hline LIV S3 & You feel safe in this city & 0 & $\mathrm{~S}$ \\
\hline MOB O1 & $\begin{array}{l}\text { Cost of a combined monthly ticket (all modes of public transport) for 5-10 } \\
\mathrm{km} \text { in the central zone - EUR }\end{array}$ & 2 & $\mathrm{D}$ \\
\hline MOB O2 & Number of registered cars per 1,000 inhabitants & 2 & $\mathrm{~S}$ \\
\hline MOB O3 & Share of journeys to work by public transport (rail, metro, bus, tram) $-\%$ & 3 & $\mathrm{~S}$ \\
\hline MOB S1 & $\begin{array}{l}\text { Means of transport primarily used to go to work/training place: public } \\
\text { transport }\end{array}$ & 0 & $\mathrm{~S}$ \\
\hline MOB S2 & Most important in my city: public transport & 0 & $\mathrm{D}$ \\
\hline MOB S3 & Public transport in the city, for example bus, tram or metro & 0 & $\mathrm{~S}$ \\
\hline
\end{tabular}


The factors were then transformed to match the desired higher values of the indicator. Most factors are de-stimulants (D). When the character changed, they became stimulants (S).

MD indicates how many data were missing for the variable. The SD column indicates whether the factor was a stimulant (S) or a de-stimulant (D).

Table 3.

Cities in the ranking

\begin{tabular}{|c|c|c|c|}
\hline CITY & COUNTRY & MD & POPULATION \\
\hline Burgas & Bulgaria & 0 & 202,694 \\
\hline Cluj-Napoca & Romania & 4 & 324,960 \\
\hline Frankfurt am Main & German & 0 & 746,878 \\
\hline Geneva & Switzerland & 0 & 200,548 \\
\hline Graz & Austria & 1 & 269,997 \\
\hline Groningen & Netherlands & 4 & 200,908 \\
\hline Kosice & Slovakia & 0 & 238,757 \\
\hline Krakow & Poland & 3 & 761,873 \\
\hline Liege & Belgium & 1 & 383,710 \\
\hline Manchester & United Kingdom & 2 & 546,564 \\
\hline Ostrava & Czech Republic & 2 & 287,968 \\
\hline Oviedo & Spain & 1 & 220,020 \\
\hline Palermo & Italy & 1 & 668,405 \\
\hline Rennes & France & 0 & 216,268 \\
\hline
\end{tabular}

Fundamental statistical indicators for the transformed variables were examined.

Table 4.

Statistical parameters of standardised indicators

\begin{tabular}{|c|c|c|c|c|c|c|c|}
\hline INDIC & Range & IQR & Quartile 1 & Quartile 2 & Quartile 3 & Skewness & Kurtosis \\
\hline ECO O1 & 2.82 & 1.63 & -1.00 & -0.16 & 0.63 & 0.13 & -1.26 \\
\hline ECO O2 & 3.74 & 0.70 & -0.56 & -0.33 & 0.14 & 2.88 & 9.25 \\
\hline ECO O3 & 3.61 & 1.40 & -0.68 & -0.06 & 0.72 & -0.33 & -0.03 \\
\hline ECO S1 & 3.62 & 1.15 & -0.61 & 0.05 & 0.54 & -0.25 & -0.04 \\
\hline ECO S2 & 3.37 & 0.89 & -0.35 & 0.17 & 0.54 & -0.82 & 0.27 \\
\hline ECO S3 & 3.38 & 1.10 & -0.70 & -0.26 & 0.40 & 0.80 & -0.14 \\
\hline ENV O1 & 3.18 & 1.67 & -0.84 & 0.04 & 0.83 & -0.10 & -1.24 \\
\hline ENV O2 & 3.22 & 1.38 & -0.81 & 0.33 & 0.57 & -0.91 & -0.52 \\
\hline ENV O3 & 3.19 & 1.34 & -0.71 & 0.40 & 0.63 & -1.29 & 0.20 \\
\hline ENV S1 & 3.03 & 1.50 & -0.80 & 0.44 & 0.71 & -0.97 & -0.52 \\
\hline ENV S2 & 4.24 & 0.91 & -0.27 & 0.13 & 0.64 & -1.24 & 3.11 \\
\hline ENV S3 & 3.94 & 0.74 & -0.21 & 0.09 & 0.54 & -1.79 & 4.57 \\
\hline PEO O1 & 3.27 & 0.58 & -0.76 & -0.47 & -0.18 & 2.21 & 4.58 \\
\hline PEO O2 & 3.43 & 0.64 & -0.56 & -0.30 & 0.08 & 0.48 & -0.16 \\
\hline PEO O3 & 2.80 & 2.09 & -1.25 & -0.20 & 0.85 & -0.09 & -1.70 \\
\hline PEO S1 & 3.84 & 0.98 & -0.66 & 0.23 & 0.32 & -0.11 & 0.24 \\
\hline PEO S2 & 3.07 & 1.55 & -0.83 & -0.11 & 0.72 & 0.28 & -1.09 \\
\hline PEO S3 & 3.35 & 0.95 & -0.24 & 0.04 & 0.71 & -1.22 & 1.16 \\
\hline LIV O1 & 3.43 & 1.16 & -0.60 & 0.01 & 0.56 & 0.42 & -0.34 \\
\hline LIV O2 & 3.72 & 1.19 & -0.44 & -0.06 & 0.76 & -1.15 & 0.97 \\
\hline LIV O3 & 3.49 & 1.43 & -0.76 & 0.36 & 0.66 & -1.39 & 0.87 \\
\hline LIV S1 & 2.65 & 1.75 & -0.94 & 0.40 & 0.81 & -0.69 & -1.29 \\
\hline LIV S2 & 3.82 & 1.14 & -0.60 & 0.40 & 0.54 & -0.79 & 0.66 \\
\hline LIV S3 & 3.38 & 1.01 & -0.23 & 0.01 & 0.78 & -0.44 & -0.30 \\
\hline
\end{tabular}


Cont. table 4.

\begin{tabular}{|c|c|c|c|c|c|c|c|}
\hline MOB O1 & 3.18 & 1.84 & -1.32 & 0.04 & 0.52 & -0.62 & -1.17 \\
\hline MOB O2 & 3.06 & 1.43 & -0.99 & -0.36 & 0.44 & 0.55 & -0.80 \\
\hline MOB O3 & 3.06 & 0.97 & -0.98 & -0.55 & -0.01 & 1.37 & 1.19 \\
\hline MOB S1 & 3.37 & 1.30 & -0.61 & 0.15 & 0.69 & -0.60 & -0.29 \\
\hline MOB S2 & 2.91 & 1.15 & -0.76 & -0.24 & 0.39 & 0.75 & -0.61 \\
\hline MOB S3 & 3.73 & 0.68 & -0.18 & 0.44 & 0.50 & -1.83 & 3.29 \\
\hline
\end{tabular}

The values of the statistical parameters indicate the differentiation between variables. There is no variable that could unambiguously distort the results of the ranking. Variables can be considered as appropriately selected.

\subsection{Methods}

The SCIwP index is based on the relationship between the area and the measurement. Let us assume that the weights for each area are the same.

The index is the arithmetic mean of indexes for each area. In the areas, indexes are based on the arithmetic mean of the indicators depending on the area. Since index design uses measures based on subjective assessments, it was decided to take into account the weight of these factors in the shape of the index.

$$
S C I w P=\frac{\sum I A_{i} w_{i}}{\sum w_{i}}
$$

for the area

$$
I A_{i}=u_{o} \frac{\sum I O_{i j} v o_{i j}}{\sum v o_{i j}}+u_{S} \frac{\sum I S_{i j} v s_{i j}}{\sum v S_{i j}}
$$

where:

$I O_{i j}$ - value of the $\mathrm{j}$-th objective variable, a measure included in the $\mathrm{i}$-th area,

$I S_{i j}$ - value of the $\mathrm{j}$-th subjective variable, a measure included in the $\mathrm{i}$-th area,

$v o_{i j}$ - weight of the $\mathrm{j}$-th objective variable, the measure included in the $\mathrm{i}$-th area, $\sum_{j} v o_{i j}=1$,

$v s_{i j}$ - weight of the $\mathrm{j}$-th subjective variable, the measure included in the $\mathrm{i}$-th area, $\sum_{j} v s_{i j}=1$,

$u_{o}$ - weight of $u_{s}$ objective variables, weight of subjective variables, $u_{o}+u_{s}=1$,

$I A_{i}$ - index value for the $\mathrm{i}$-th area,

$w_{i}$ - the weight of the $\mathrm{i}$-th area, $\sum_{i} w_{i}=1$,

all weights are non-negative.

The ranking is set for values $u_{o}$ that change from 0 to $100 \%$ every $10 \%$. 


\section{Results and discussion}

According to the methodology presented, the following ranking of cities was obtained.

Table 5.

City Ranking SCIwP

\begin{tabular}{|c|c|c|c|c|c|c|c|c|c|c|c|}
\hline \multirow{2}{*}{ CITY } & \multicolumn{10}{|c|}{ SHARE OF OBJECTIVE INDICATORS } \\
\cline { 2 - 14 } & $\mathbf{1 0 0 \%}$ & $\mathbf{9 0 \%}$ & $\mathbf{8 0} \%$ & $\mathbf{7 0 \%}$ & $\mathbf{6 0 \%}$ & $\mathbf{5 0} \%$ & $\mathbf{4 0} \%$ & $\mathbf{3 0} \%$ & $\mathbf{2 0 \%}$ & $\mathbf{1 0} \%$ & $\mathbf{0 \%}$ \\
\hline Geneva & 1 & 1 & 1 & 1 & 1 & 1 & 1 & 1 & 1 & 1 & 3 \\
\hline Frankfurt am Main & 2 & 2 & 3 & 3 & 3 & 3 & 3 & 4 & 8 & 8 & 8 \\
\hline Groningen & 3 & 3 & 2 & 2 & 2 & 2 & 2 & 2 & 2 & 2 & 2 \\
\hline Manchester & 4 & 4 & 4 & 4 & 4 & 4 & 5 & 5 & 7 & 7 & 7 \\
\hline Rennes & 5 & 5 & 5 & 5 & 5 & 5 & 4 & 3 & 4 & 4 & 4 \\
\hline Oviedo & 6 & 6 & 6 & 6 & 6 & 6 & 6 & 6 & 5 & 5 & 5 \\
\hline Burgas & 7 & 7 & 7 & 7 & 7 & 7 & 7 & 7 & 6 & 6 & 6 \\
\hline Kosice & 8 & 8 & 8 & 8 & 8 & 8 & 8 & 9 & 9 & 9 & 9 \\
\hline Palermo & 9 & 12 & 13 & 14 & 14 & 14 & 14 & 14 & 14 & 14 & 14 \\
\hline Ostrava & 10 & 9 & 10 & 10 & 11 & 11 & 11 & 11 & 11 & 11 & 11 \\
\hline Graz & 11 & 11 & 12 & 12 & 13 & 13 & 13 & 13 & 13 & 13 & 13 \\
\hline Liege & 12 & 13 & 11 & 11 & 12 & 12 & 12 & 12 & 12 & 12 & 12 \\
\hline Krakow & 13 & 10 & 9 & 9 & 9 & 9 & 10 & 10 & 10 & 10 & 10 \\
\hline Cluj-Napoca & 14 & 14 & 14 & 13 & 10 & 10 & 9 & 8 & 3 & 3 & 1 \\
\hline
\end{tabular}

The results for a ranking based only on objective measures were analysed. The best city is Geneva. Second place goes to Frankfurt am Main. The fact that these cities have taken these places in the ranking is in line with expectations, with the well-known high-ranking city of Manchester is also expected. The Romanian city of Cluj-Napoca closes the ranking. One might think that the ranking of a given city depends on the economic position of the country. In this case, Krakow's position seems too low.

Changing the share of subjective measures from 0 to $70 \%$ does not result in major changes in the first five places. For a share of $20 \%$ to $50 \%$, Groningen and Frankfurt am Main change positions. The reasons can be the location of one of the largest airports in the world which results in nuisance for residents. This results in a decrease in the city's ranking.

In the last eight places, there are the same cities. However, the changes are much more dynamic. It is shown how the position of a given city in the ranking in relation to the ranking based on subjective measures is determined. 
Table 6.

Absolute differences in places in the rankings

\begin{tabular}{|c|c|c|c|c|c|c|c|c|c|c|}
\hline \multirow{2}{*}{ CITY } & \multicolumn{9}{|c|}{ SHARE OF OBJECTIVE INDICATORS } \\
\cline { 2 - 12 } & $90 \%$ & $80 \%$ & $70 \%$ & $60 \%$ & $50 \%$ & $40 \%$ & $30 \%$ & $20 \%$ & $10 \%$ & $0 \%$ \\
\hline Geneva & 0 & 0 & 0 & 0 & 0 & 0 & 0 & 0 & 0 & 2 \\
\hline Frankfurt am Main & 0 & 1 & 1 & 1 & 1 & 1 & 2 & 6 & 6 & 6 \\
\hline Groningen & 0 & 1 & 1 & 1 & 1 & 1 & 1 & 1 & 1 & 1 \\
\hline Manchester & 0 & 0 & 0 & 0 & 0 & 1 & 1 & 3 & 3 & 3 \\
\hline Rennes & 0 & 0 & 0 & 0 & 0 & 1 & 2 & 1 & 1 & 1 \\
\hline Oviedo & 0 & 0 & 0 & 0 & 0 & 0 & 0 & 1 & 1 & 1 \\
\hline Burgas & 0 & 0 & 0 & 0 & 0 & 0 & 0 & 1 & 1 & 1 \\
\hline Kosice & 0 & 0 & 0 & 0 & 0 & 0 & 1 & 1 & 1 & 1 \\
\hline Palermo & 3 & 4 & 5 & 5 & 5 & 5 & 5 & 5 & 5 & 5 \\
\hline Ostrava & 1 & 0 & 0 & 1 & 1 & 1 & 1 & 1 & 1 & 1 \\
\hline Graz & 0 & 1 & 1 & 2 & 2 & 2 & 2 & 2 & 2 & 2 \\
\hline Liege & 1 & 1 & 1 & 0 & 0 & 0 & 0 & 0 & 0 & 0 \\
\hline Krakow & 3 & 4 & 4 & 4 & 4 & 3 & 3 & 3 & 3 & 3 \\
\hline Cluj-Napoca & 0 & 0 & 1 & 4 & 4 & 5 & 6 & 11 & 11 & 13 \\
\hline MAX & 3 & 4 & 5 & 5 & 5 & 5 & 6 & 11 & 11 & 13 \\
\hline Average & 0.57 & 0.86 & 1.00 & 1.29 & 1.29 & 1.43 & 1.71 & 2.57 & 2.57 & 2.86 \\
\hline
\end{tabular}

In this group of cities, already $10 \%$ influence of subjective variables causes Palermo to fall in the ranking by three places. Krakow, on the other hand, is growing by three places. The opinion of the inhabitants about Palermo makes the city take much lower position in the ranking than the objective measures show. The biggest change is recorded in the Romanian city of Cluj-Napoca. Thanks to the opinion of the inhabitants, this city could even be in the first place in the ranking.

They looked at which areas influenced the ranking for Geneva and Cluj by comparing them with the average scores for the group of cities studied. It turned out that the most important factors for the ranking are factors related to the areas: smart economy, ECO, intelligent mobility. Residents of Cluj-Napoca believe that they have no problems with finding good work, unemployment or payment for bills. When assessing smart mobility, they also use urban transport and they have no reservations to it.

Geneva's example shows that people have a relatively poorer view of areas: smart economy ECO, intelligent mobility MOB, intelligent environment ENV, intelligent living conditions LIV. These results are close to average values. On the other hand, the area of the intelligent population PEO is strongly assessed; the results in this area are moving away from the average. 


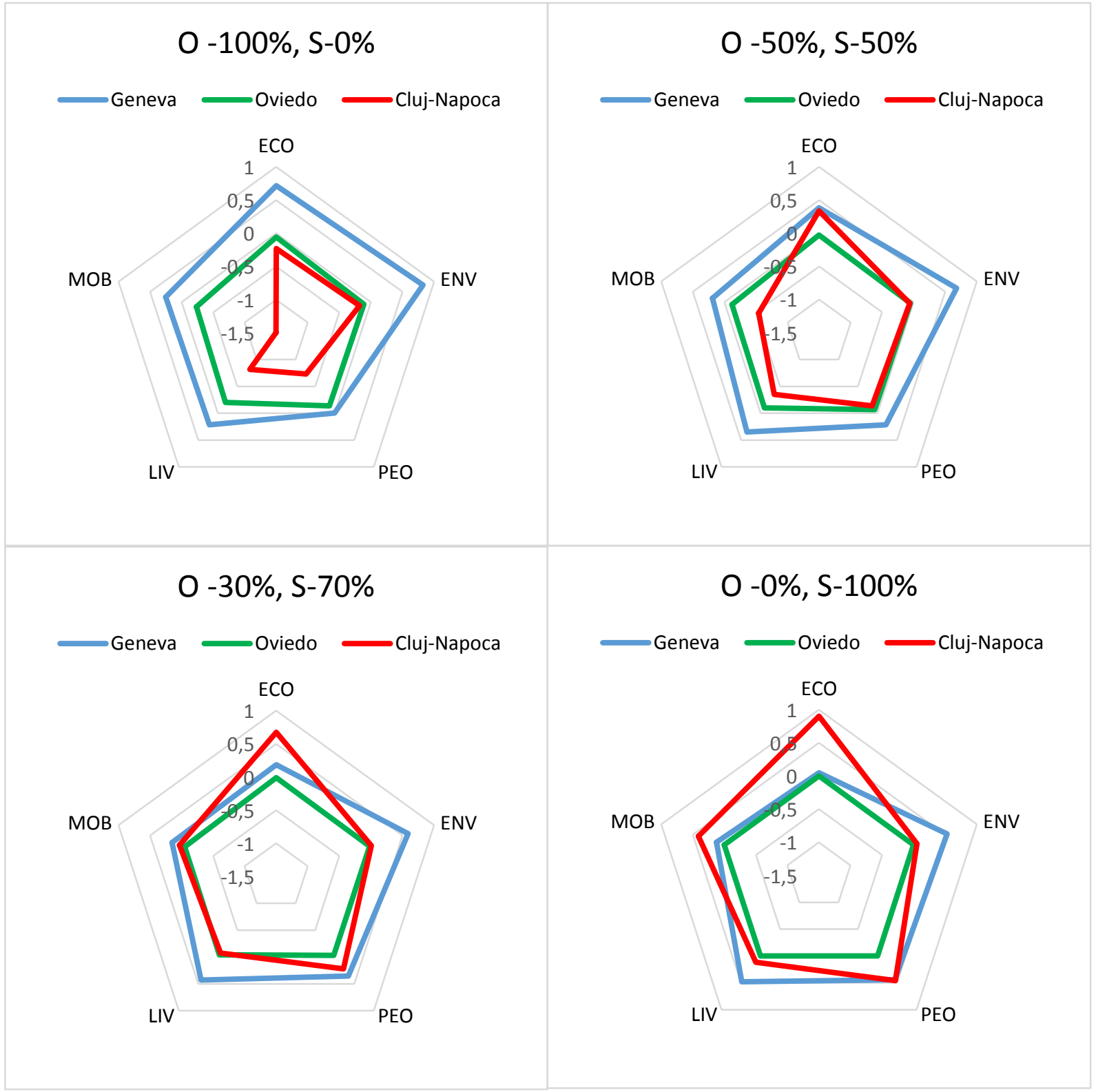

Figure 1. Comparison of areas for selected cities with different share of objective indicators.

\section{Conclusion}

In city rankings, it is also worth paying attention to subjective factors. The assessment of residents should be taken into account. The idea of Smart City is to be a concept of a city friendly to its inhabitants. The voice of the city's inhabitants should be included in the rankings. In the example analysed, the city of Cluj-Napoca has a better ranking than Geneva in the inhabitants ratings.

Further work on this topic should be carried out to establish a fair share of subjective assessments in constructed indexes. 


\section{References}

1. Ahvenniemi, H., Huovila, A., Pinto-Seppä, I., Airaksinen, M. (2017). What are the differences between sustainable and smart cities? Cities, 60, pp. 234-245.

2. Albino, V., Berardi, U., Dangelico, R.M. (2015). Smart cities: Definitions, dimensions, performance, and initiatives. Journal of Urban Technology, 22(1), pp. 3-21.

3. Berrone P., Ricart J.E., Duch A., Carrasco C. (2019). IESE Cities in Motion Index 2019, IESE, ST-509-E, 05/2019 DOI: https://dx.doi.org/10.15581/018.ST-509.

4. Bosch, P., Jongeneel, S., Neumann, H.-M., Branislav, I., Huovila, A., Airaksinen, M., PintoSeppä, I. (2017a), Recommendations for a Smart City index. CITYkeys - Smart city performance measurement framework. DOI: 10.13140/RG.2.2.20190.74562, 16.04.2020.

5. Bosch, P., Jongeneel, S., Rovers, V., Neumann, H.-M., Airaksinen, M., Huovila, A. (2017b). CITYkeys indicators for smart city projects and smart cities. CITYkeys - Smart city performance measurement framework. DOI: 10.13140/RG.2.2.17148.23686, 16.04.2020.

6. Giffinger, R., Fertner, C., Kramar, H., Kramar, H., Kalasek, R., Pichler-Milanovic, N., Meijers, E. (2007). Smart Cities. Ranking of European medium-sized cities. Centre for Regional Science, Vienna University of Technology, http://www.smart-cities.eu/download/ smart_cities_final_report.pdf, 16.04.2020.

7. Huovila, A., Penttinen, T., Airaksinen, M., Pinto-Seppä, I., Piira, K., Penttinen, T. (2016, September). Smart city performance measurement system. Proceedings of the 41st IAHS World Congress Sustainability Innovation for the Future, Algarve, Portugal, pp. 13-16.

8. Kukuła, K. (1989). Statistical structural analysis and its application in the field of production services for agriculture. Scientific Notebooks AE in Krakow, Special series: Monographs, 89 , p. 256.

9. Kukuła, K. (2000) Method of zeroed unitarisation. Warsaw: PWN.

10. Lombardi, P., Giordano, S., Caragliu, A., Del Bo, C., Deakin, M., Nijkamp, P., Kourtit, K. (2011). An advanced triple-helix network model for smart cities performance. Vrije Universiteit Amsterdam, Research Memorandum 2011-45, http://degree.ubvu.vu.nl /repec/vua/wpaper/pdf/20110045.pdf, 15.03.2019.

11. Smart City PROFILES (2013). Ergebnisse. 7.6.2013. http://www.smartcities.at/assets/03Begleitmassnahmen/SmartCity-PDF-INTRO.pdf, 16.03.2020.

12. Sojda, A., Owczarek, T., Wolny, M. (2018). Smart city in data-oriented terms - Poland in eurostat - database. Zeszyty Naukowe PŚl., Org. Zarz., z. 130, p. 557-566, DOI: 10.29119/1641-3466.2018.130.46.

13. Sojda, A., Wolny, M. (2020). The impact of standardisation method on smart city ranking, Sil. Univ. Technol. Sci. Pap., Organ. Manage., no. 142, pp. 83-94, DOI: 10.29119/16413466.2020.142.6. 
14. Stankovic, J., Dzunic, M., Džunić, Ž., Marinkovic, S. (2015). A multi-criteria evaluation of the European cities' smart performance: Economic, social and environmental aspects. Zbornik radova Ekonomskog fakulteta u Rijeci, časopis za ekonomsku teoriju i praksuProceedings of Rijeka Faculty of Economics. Journal of Economics and Business, 35(2), pp. 519-550.

15. Svítek, M., Skobelev, P. Kozhevnikov (2020). Smart City 5.0 as an Urban Ecosystem of Smart Services. 10.1007/978-3-030-27477-1_33.

16. Szczech-Pietkiewicz, E. (2015). Smart city-sample definition and measurement. Scientific work of the University of Economics in Wroclaw. Local economy in theory and practice, 391.

17. Tahir, Z., Malek, J.A. (2016). Main criteria in the development of smart cities determined using analytical method. Planning Malaysia Journal, 14(5).

18. UCLG (2012). Smart Cities Study: International study on the situation of ICT, innovation and knowledge in cities. Bilbao. http://www.uclg-digitalcities.org/app/uploads/2015/06 /en_smartcitiesstudy.pdf, 16.04.2020.

19. United Nations (2014). World urbanization prospects: The 2014 Revision, Highlights (ST/ESA/SER.A/352). New York. United States of America, https://doi.org/10.4054/ DemRes.2005.12.9. 